Māra Urdziṇa-Deruma, Mārīte Kokina-Lilo, Gunta Treimane, Lolita Šelvaha

University of Latvia, Latvia

\title{
LATVIAN PUBLIC OPINION ON THE QUALITY OF HOME ECONOMICS AND TECHNOLOGIES
}

\begin{abstract}
At the moment in Latvia, general education reform is being implemented, introducing a competence-based learning approach and content. While implementing education reform, it is vital to learn public opinion. The goal of this study is to explore Latvian public opinion on the acquisition of materials processing technologies in comprehensive schools by finding out what Latvian society understands through a qualitative process of materials processing technologies' acquisition. In the study a questionnaire methodology has been used. The results are analysed from a qualitative and quantitative point of view. The obtained results show that Latvian society considers educators' competence and the materials supplies of workshops to be the most essential aspects for ensuring a quality Home Economics and Technologies subject. The respondents think that the domestic and practical skills and competencies are the key input in pupils' education. When expressing an opinion on the necessary changes, the largest percentage of respondents wanted to improve the content of learning and to include more practical tasks. Respondents' opinions are divided on the question as to whether all topics that have traditionally been optional should be mastered by all pupils equally. Respondents pay little attention to the aesthetic and cultural aspect, as well as the skills of creating craft design and artistic expression.
\end{abstract}

Keywords: home economics and technologies subject, quality of craft education, content of learning, craft skills.

\section{Introduction}

In Latvia, the subject Home Economics and Technologies has undergone changes both in name and goals, as well as a different subject curriculum. In each period of history, there have been different focuses on the subject's goals and curriculum. Already during the first Free State of Latvia 
(1918-1940) specialists of Home Economics and manual training saw the diverse importance of handiwork in personal development: physical development; preparation for practical life; linking theoretical knowledge to practice; development of creative capacities; and teaching taste of art (Urdziņa-Deruma, Mīlgrāve, 2014, p. 118). In the Soviet period (19401990) the major focus was on poly-technical education and production training (Žukovs, 1987). Since the occupation of Latvia and annexation by the USSR until the present, the curriculum of home economics has been embracing acquisition of various manual training techniques within one subject. In the current valid Home Economy and Technologies Standard (Noteikumi par valsts pamatizglītības standartu, pamatizglītības mācību priekšmetu standartiem un pamatizglìtības programmu paraugiem, 2014) both pupils' practical creative activities ranging from an idea to a creative product (including evaluation of the activity and work process) as well as promotion of cooperative skills have been emphasised. Regarding content, the subject is very similar to Estonia's model, where one subject contains both Home Economics and Craft (National curriculum for basic schools, 2014). In Latvia, the acquirable curriculum of Technologies is similar to the Craft curriculum (e.g., Käsitöö in Finland (Pöllänen, 2009) or Sloyd in Sweden (Borg, 2006)). In the context of a subject term, "Technologies" is understood as a processing of various materials (textiles, wood, metal, and others). In the Home Economics and Technologies standard it is defined as "For the acquisition of the technological process of product making, school offers two equivalent programmes for pupils that mainly differ in the choice of materials needed for product making and processing specifics: I technologies for textile and similar materials II - technologies for wood, wooden materials, metal and other similar materials" (Noteikumi par valsts pamatizglītības standartu, pamatizglītības mācību priekšmetu standartiem un pamatizglītibas programmu paraugiem, 2014).

An extensive education reform is being implemented for a transition toward a competence approach (Izglītība mūsdienu lietpratībai: mācību satura un pieejas apraksts, 2017), which affects each subject and the learning process in general; therefore, it is necessary to cover not only the foreign studies but also comprehensive research in education, including identification of public opinion.

The goal of this study is to explore Latvian public opinion on the acquisition of materials processing technologies in comprehensive schools by finding out what Latvian society understands by a qualitative process of materials processing technologies' acquisition.

In the "Explanatory Dictionary of Pedagogical Terms" (Blinkena, 2000, p. 90) quality is defined as "An indication, feature or set that characterises compliance of a subject, phenomenon or process to certain predetermined 
(imposed) requirements. In the pedagogical process the quality of consecutively related processes and their results is of vital significance."

The unique situation of Latvia in the context of the EU and the world should also be taken into account, and an appropriate model of materials processing technologies should be created. Fadels, Bialika, and Trilings (2017, pp. 34-36) indicate that for a $21^{\text {st }}$ century learning programme to be truly holistic, it should contain and be able to balance different educational objectives. The authors present numerous examples, from which the most important ones for this study are: balance between modern knowledge and traditional subjects; balance between profundity and breadth; balance between natural sciences, technologies, engineering, mathematics (STEM), and the humanities and art; balance between mind and body; balance between knowledge, skills, character, and meta-learning; and balance between outcome and process. One questions is: what modern knowledge should be included in the Home Economy and Technologies subject, and how profoundly and extensively each topic in the Home Economy and Technologies content should be learned. A balance between natural sciences, technologies, engineering, mathematics (STEM), and the humanities and art should be found in the very subject of Home Economy and Technologies. As M. Urdzina-Deruma (2001) has investigated in her doctoral thesis, textile technologies should be learned in the framework of artistic education. Acquisition of other materials processing technologies can be justified similarly, because artistic means of expression and principles are used when creating products; consequently, it is a language of art. Luutonen, et al. (1999, p. 7) and Ihatsu (2002, pp. 54-77) show the close link between art, design, and craft. Ihatsu (2002) writes that craft and art have close points of contact, art-craft being the intermediary between the two. The close correlation between craft and art is indicated also by the fact that in Norway there's a subject called "Arts and Crafts" (Lutnces, 2013, p. 76). In the currently proposed content model within the framework of project "Competence approach in the learning content" (Izglītība mūsdienu lietpratībai: mācību satura un pieejas apraksts, 2017) the learning content of Home Economy and Technologies is included in the domain of "Technology", not "Art and Cultural Awareness". It is similar to Estonia, where subjects related to handicraft are included in the domain of technology. "Although the name of the domain suggests a technical orientation of the subject, the content pays a lot of attention on developing the creative side. It is important to point out that the syllabus indicates the connections between handicraft and applied art" (Lind, 2013, p. 156). Anspaks (2006, p. 250) alerts us about the pressure of one-sided intellectualism, rationalism, and the prevailing technocracy and practicism. Traditionally, in the subject content the cultural dimension 
was of great importance, as indicated also by Lind (2013, p. 156). Finnish researcher Ihatsu (2002, p. 54) has explored that handicraft has always been an important part of culture. Latvia has adopted the Intangible Cultural Heritage Law (2016), which determines that intangible cultural heritage, including traditional craft skills, should be incorporated in both formal and informal education. What is stated in the law relates to Anspaks' (2006, p. 23) idea that without unity of change and preservation principles and their interaction it is not possible to achieve a genuine implementation of educational opportunities. In theory and practice of any cultural domain, inheritance and succession help to retain thoroughness.

In relation to the example suggested by Fadels, Bialika, and Trilings, in the search for balance between mind and body, Home Economics and Technologies gives the chance to practice a healthy diet as well as develop the mind, sight, and hands in a coordinated manner. In Home Economics and Technologies, possibly more than in other subjects, the acquisition of learning content can be balanced with practical skills applicable in the real world, and it can stimulate the development of character traits. Swedish researcher Johansson (2006, p. 169) has explored that in handicraft lessons the learning process is very similar to life situations outside the classroom. The final result is directly related to the pupils' working process. Very often the outcome is a product that can be practically used.

By learning technologies, it is very important to apply a balance between results and processes. In the opinion of the authors, it means paying equal attention to the creation process of the product by taking the product design, formation of composition, selection of materials, and technique/technologies, as well as experimental opportunities and aesthetic and technically qualitative results into consideration. Only then does the product give pleasure and satisfaction, and develops patience and other important character traits. Fadels, Bialika, and Trilings (2017, p. 5657) point out that each subject holds three value aspects: 1) the practical aspect that is related to applicability in everyday life; 2) the cognitive aspect that refers to the development of the highest level and development of character; and 3) the emotional aspect reflecting the fact that the subject possesses beauty and power to help understand the world. Crafts are related to many spheres of life. The model provided by Kaukinen (2006, p. 149) shows the necessary skills for craft-making from material to cultural artifacts. The development of craft design skills is influenced by the culture, technologies, and the personal skill to make decisions and experience in the creation of craft design. Borg (2006, pp. 42-45) points out that an essential part of the craft (Sloyjd) subject identity is the aesthetic aspect; craft education promotes aesthetic preparedness, and it develops an understanding of how selection of the material, processing, 
and designing affects the functionality and durability of the objects. Pupils should be educated about the environment, safety, and the importance of prudent use of resources. Teaching should be tied to the national cultural heritage of handicraft and foreign cultures. Handicraft belongs to the cycle of aesthetic subjects.

Finland's craft science model defines domains that need to be respected, because craft products are related to several aspects: cultural; social; temporality; environmental; and economic. The tangible and intangible characteristics of a craft product are interlinked. Their inseparability is reflected in the concept of aesthetics. The aesthetic qualities are dependent on the material, structure, method of creation, and the cultural perception of the material's characterisation. (Luutonen, et al., 1999, pp. 3-6). The aesthetic quality of the product is also taken into account when assessing pupils' craft products (Syrjäläinen \& Seitamaa-Hakkarainen, 2014). Similar to craft product, craft science is related to many sciences: psychological; cognitive; social; cultural-historical; and socioeconomic, as well as the natural sciences' and technologies' dimensions of human activities (Luutonen, et al., 1999, pp. 3-6).

As Elorinne, Arai, and Autio $(2017,145)$ point out, "Home Economics is constructed as both a practical discipline and as a human science. The field of Home Economics has a specific cultural research object: the household and its activities".

In today's global context the skills to be acquired in the $21^{\text {st }}$ century are defined; they can be broadly acquired in the Home Economics and Technologies subject. Finnish researchers distinguish two types of craftmaking processes: the holistic one that includes generation of an idea, experiments, creation of the product, and analysis of the result, as well as the ordinary one, where the handicraft is being made by following a sample. Pöllänen (2009) looks at four pedagogical models for learning craft at school: craft as product-making; craft as skill and knowledge-building; craft as design and problem-solving; and craft as self-expression. In each of these pedagogical models, the teacher's role is different. In the model of craft as product-making the teacher uses already-prepared samples called "ordinary craft" because in most cases the technique and materials are already defined. Craft as skill and knowledge-building is like a transitional phase between ordinary craft and holistic craft. The greatest emphasis is laid on skill acquisition in dealing with materials and techniques. Craft as design and problem-solving fully complies with holistic craft, because it includes solving a real problem, generating an idea, experimenting with materials and techniques, and making a design product with a practical function. The model of craft as self-expression also complies with holistic craft: in this model, the emphasis is on pupils' self-expression in the 
process of product creation, whereas the teacher is responsible for creating a supportive environment.

Root-Bernstein's study (2015, pp. 206-207) shows that “... here is a compelling statistical correlation between the highest levels of creative success and entrepreneurial endeavors in mathematics, science, and engineering and persistent participation in arts and crafts from childhood through Professional training and into career years. ...Arts and craft provide STEM students and professionals with (1) mental skills such as observing, imaging and abstracting, (2) sensual and manipulative skills, (3) analogies that provide novel approaches to solving STEM problems, (4) experience with materials, structures, phenomena and techniques, (5) practice with creative process; and (6) recreation to relax and re-energise their minds".

In the framework of education reform, the question of gender equality has become highly topical. By designing the content of future material processing technologies, an idea that all pupils should acquire all subject content has been put forward. However, Kalke, and Gonzalez Urrea (2016, p. 64) have explored that gender-differentiated education owes its origins to the ancient world (Mesopotamia), and such a way of learning had been particularly apparent in the Middle Ages. Presently, such an organization of educational activity is being practised in many countries, where boys and girls are learning separately. These may be schools, grades, or separate lessons where pupils are differentiated by gender. Historically, the Home Economics and Technologies subject was officially divided according to gender starting from the $5^{\text {th }}$ grade. For certain periods, that had started from the $4^{\text {th }}$ grade. As of 1998, the content of learning is not divided according to gender; in grades 1-4 all pupils learn the subject together but starting from the $5^{\text {th }}$ grade each pupil can choose whether to learn textiles and other similar materials or wood, metal technologies, and other similar technologies, but all of them should acquire Home Economics (Mājturība. Pamatizglìtības standarts, 1998; Noteikumi par valsts pamatizglìtības standartu, pamatizglìiîbas mācību priekšmetu standartiem un pamatizglìīibas programmu paraugiem, 2014).

\section{The methodology of the study}

A questionnaire was used in the study. The questionnaire contained multiple-choice questions and open questions. The questionnaire was distributed in paper format and over the internet. The respondents were asked to fill out the questionnaire to express their opinion with the aim of developing the learning content of Home Economics and Technologies. The pilot study was carried out from March 2017 to May 2017. Then the acquired data were analysed and more questions were added to the questionnaire. 
The basic study was carried out from June 2017 until April 2018. The aim of the research was to find out what the Latvian public understands with the acquisition of a high-quality Home Economics and Technology subject.

Questions of the study:

- In the view of respondents, what is a qualitative process of Home Economics and Technologies acquisition?

- What qualities does acquisition of Home Economics and Technologies develop in pupils?

- Where is the knowledge, skills, and competencies gained in Home Economics and Technologies used/applied?

- Which material processing technologies need to be included in the content of Home Economics and Technologies?

- In what directions should the content of Home Economics and Technologies be developed?

- Should all pupils learn an identical content of learning in Home Economics and Technologies or is an optional choice necessary?

- Which of the pedagogical models of handicraft learning suit to the expectations of Latvian society?

Both qualitative and quantitative methodologies have been used in the study. According to the methodology of the qualitative study, respondents' answers to the open questions were gathered in tables and grouped by making up categories (Kroplijs \& Raščevska, 2010). Then the categories were analysed quantitatively, whereas the answers to multiple-choice questions were analysed quantitatively.

\section{Characterisation of the respondents}

The respondents totaled 1,068: 942 or $88 \%$ were women and $12 \%$ or 126 were men. $68 \%$ of respondents had higher education, $12 \%$ had secondary professional education, $11 \%$ had secondary education, $6 \%$ had an unaccomplished higher education. The ages of respondents ranged from 15 to 92 years. Respondents represented all of Latvia: 33\% of respondents represented the small towns; 29\% represented Riga; 26\% represented the countryside; and 12\% represented the biggest cities of Latvia.

Occupations of the respondents participating in the survey were aggregated in accordance with the provisions regarding classification of occupations, basic tasks appropriate to an occupation and basic requirements of qualification (2017), where occupations were classified in accordance with the International Labour Organisation's (2008) International Standard classification of occupations ISCO-08, and were grouped into ten major groups in ascending order. Most respondents had occupations belonging to the second major group (see Figure 2). 


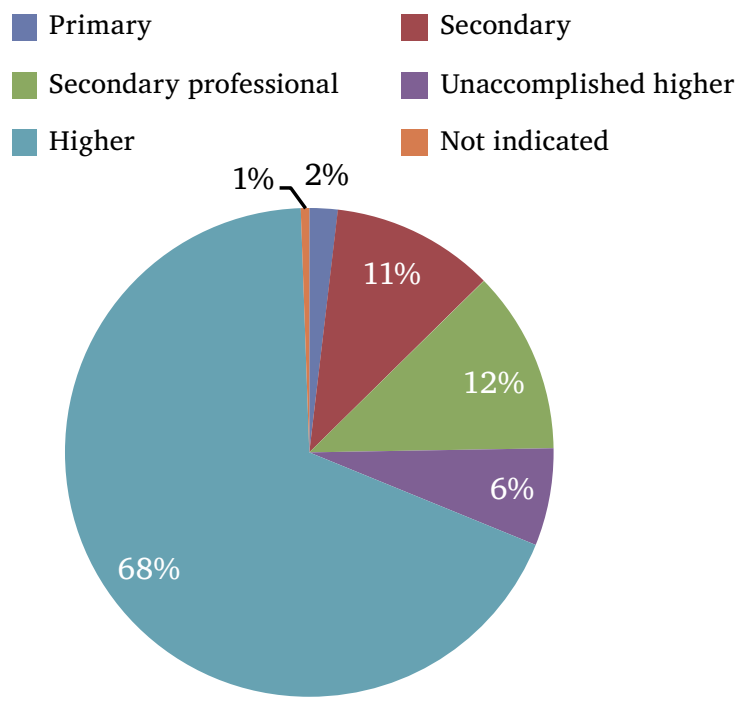

Figure 1. Education of the respondents

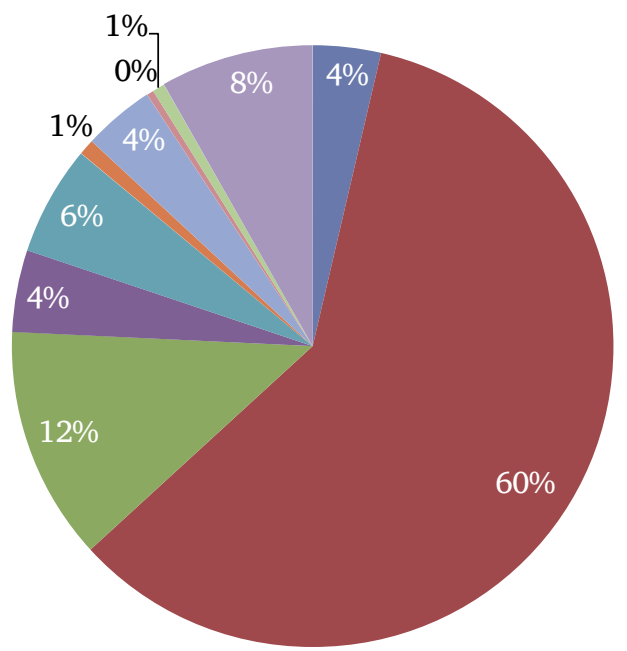

1. Heads of companies and institutions

2. Teachers, doctors, lawyers, scientists, artists, engineers, etc.

3. Specialists of various domains, technologists, culture professionals

4. Clerks, administrators, secretaries, accountants

5. Employees of service sector

6. Farmers, pisciculturists, forest labourers

7. Craftsmen, woodworkers, handicraftsmen, florists, tailors

8. Drivers, machine-operators

Figure 2. Occupations of the respondents

\section{Results of the study}

$90 \%$ of respondents thought that Home Economics and Technologies is an important subject, 6\% thought that it is an unimportant subject, $4 \%$ gave other replies. Respondents' answers testified that the Home Economics and Technologies subject has had a significant role in their lives, and for $36 \%$ of respondents it had influenced their choice of profession, for $68 \%$ 
of respondents it had influenced the choice of a hobby, and for $74 \%$ of respondents it had influenced their everyday lives.

For $32 \%$ of respondents the most important category for describing a qualitative acquisition process of Home Economics and Technologies was the teacher (see Figure 4), such as their competence, engagement, creativity, positive attitude, novelty, the ability to engage, experience, the teacher's personality, and talent (see Figure 3). Some respondents named several qualities that are important for a teacher, for example:

S17 A professional, creative and inspiring teacher.

J26 A proficient and creative teacher.
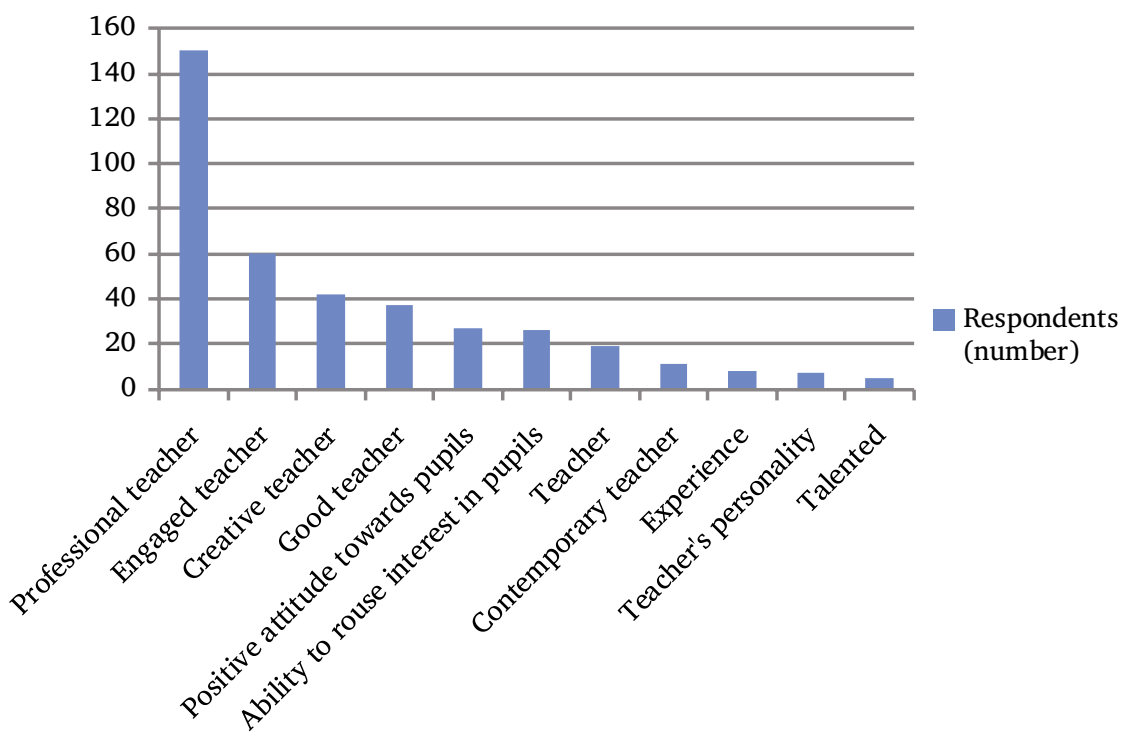

Figure 3. Respondents' views concerning the teacher - provider of qualitative Home Economics and Technologies subject

$24 \%$ of respondents thought that the most important category for describing the quality of Home Economics and Technologies was a qualitative material supply base, accessible materials, and the latest technologies. Respondents expressed it in various ways by mentioning it generally or by giving specific examples referring to the learning of a specific technology.

M15 A spacious, qualitative and modern material supply base

K5 Well-equipped rooms with all necessary equipment (sewing-machines, looms, kitchen, stoves, furnaces)

MK17 Workbenches should be available at schools where pupils can practice wooden and metal works 
119 respondents pointed out that quality was reflected by motivated and engaged pupils. Fewer respondents (106) thought that the indicator of quality was the fact that the mastered skills could be applied in the household. It follows that $1 / 10$ of all respondents thought that the subject should teach skills applicable in the household. A comparatively small part of respondents viewed the quality of the subject as skills achieved by the pupil and the pupil's ability to make use of the learned skills (94 respondents). 80 respondents thought that qualitative acquisition of Home Economics and Technologies was proven by novelty in content and implementation. 66 respondents mentioned creativity as a category representing quality. Ihatsu wrote (2002, p. 18) that the process of handicraft creativity is understood as an extensive and integrated phenomenon. 63 respondents pointed out practical work as a category of quality. As a category representing quality 45 respondents indicated this result, whereas 44 respondents indicated enjoyment of pupils attending Home Economics and Technologies classes. A similar number of respondents $(31,29,28)$ mentioned application of skills, production of products and, application of up-to-date technologies, respectively, as a category of quality (see Figure 4).

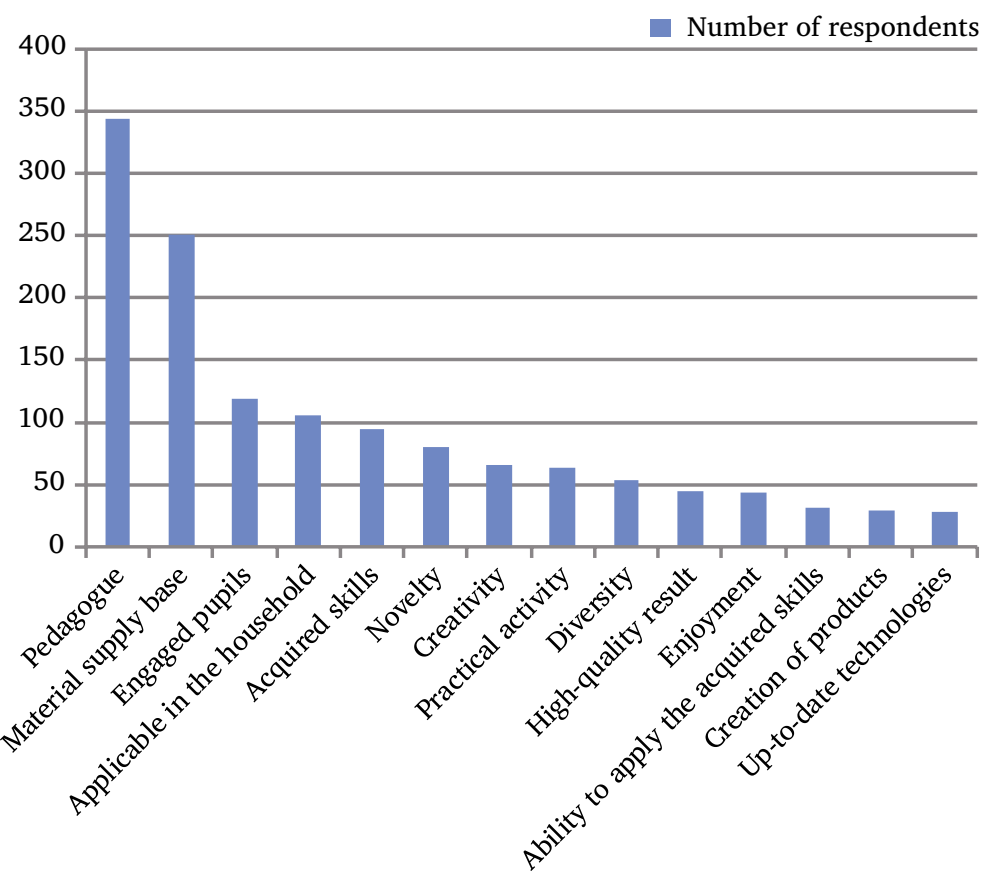

Figure 4. Respondents' views concerning categories that represent qualitative acquisition of Home Economics and Technologies subject 
The obtained results comply with Ihatsu's opinion (2002, p. 23-24) that acquisition of skills is an emotional, intellectual, and physical process, instead of just a mechanical process, and that acquisition of practical knowledge is a slow process. Tacit knowledge is always contained in practical skills, and it is fundamentally necessary for society to create ideas. This knowledge is learned by senses and practical experience.

Just a few respondents (less than 1\%) characterising quality of Home Economics and Technologies mentioned the learning programme, diversity of topics, assessment of pupils' learning achievements, exhibition of their works, achievements in olympiads, division and non-division in genders, implementation of cross-curricular links, use of excursions, as well as the use of knowledges and skills gained in Home Economics and Technologies when choosing a hobby or a profession, inheritance of traditional culture, and parents' attitude toward the subject (see Figure 5). 5\% of respondents did not answer this question.

Respondents' answers prove that in Latvian society a comparatively large percentage of people are engaged in various types of handicraft

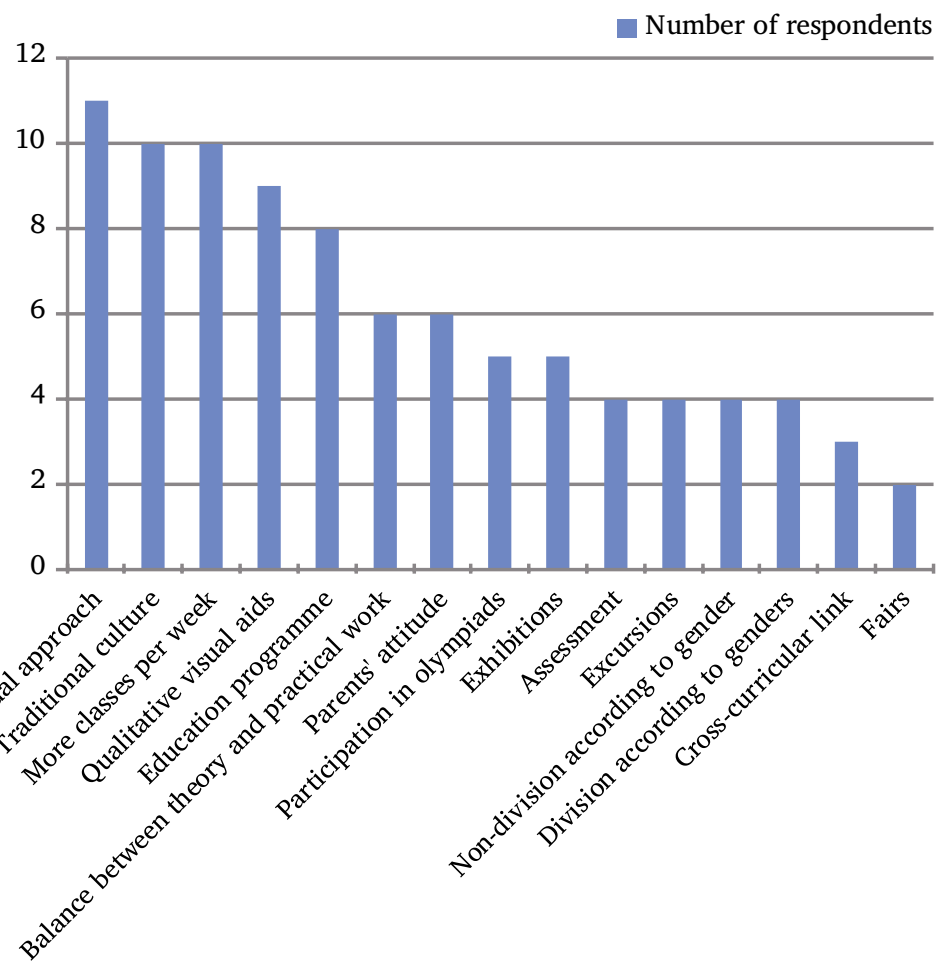

Figure 5. Respondents' views concerning categories that represent qualitative acquisition of Home Economics and Technologies subject 
because $94 \%$ of respondents did repair works, 93\% made various products manually, and $86 \%$ made various handicraft together with children.

In the context of education reform, the issue of whether all pupils should learn all topics has caught attention. Respondents held different viewpoints on this question: $48 \%$ of respondents thought that pupils should be given a choice to learn the technologies as before, whereas $41 \%$ of respondents thought that all pupils should learn all topics. $11 \%$ of respondents gave a different answer.

The highest share of answers to the question "What teaching topics were absent in Home Economics and Technologies that you would like to learn?" was related to textiles (42\% of all respondents; $46 \%$ of women and $10 \%$ of men). Many respondents emphasised that they would have liked to have had more classes and they would have liked to have learned sewing and traditional handicraft like knitting, crochet, embroidery, weaving, and card weaving in greater depth. Many respondents noted that they would have liked to have learned these techniques according to modern technological possibilities and new materials. For example, in knitting - loom knit; in embroidery - ribbon embroidery or machine embroidery; and in weaving - pearl weaving. Many textile techniques were named in relation to fashion trends, such as textile mosaics, various creative decorative techniques of fabrics, pearl knitting, and synthesis of various textile techniques. Many respondents wanted to learn such fabric decorating methods as printing, batik, and silk painting. Related to sewing, basic knowledge of sewing, clothing construction and modelling, as well as clothing culture, etiquette, and care of clothes were mentioned. Some specific products were also mentioned as ones that should be learned in greater depth, such as knitting of socks and caps and weaving of dolls. It was also requested to dye yarns with natural and synthetic dyes.

The second most popular topic was wood and metal $(32 \%$ of respondents). This category was mostly mentioned by men (48\%) and $30 \%$ of women. Women believed that girls should be taught "boys' works and learning topics" like woodworking and metal. Girls should learn the traditional working tools and skills of these materials. Women held an opinion that girls should also know how to carry out small repairs indoors, as well as repairs of electrical devices and furniture. Some respondents named specific skills like how to hammer in a nail, how to screw, turn, shave, etc. Men held an opinion that skills in work with electrical machinery and electrical devices should be learned in terms of both using and repairing them, and basics of electrical installations should be learned. In woodworking specific skills and processing types, such as joinery, wood-carving, and wood-engraving were mentioned. Such skills as repairing domestic appliances and rooms were also named. 
Men suggested also knowledge of plumbing works and learning of specific materials and skills, such as stone engraving. Both women and men mentioned driving skills and car mechanics. The need for technical graphics skills was also named for the purpose of reading technical drawings and designing.

The third largest category was related to various materials, their application, new technological opportunities, and development of specific skills and competencies ( $23 \%$ of respondents). Respondents named ceramics and clay modelling, decoupage, floristics and flower arranging, leather processing, bookbinding, candle-making, glass painting, wicker-work, giftwrapping, and preparation of greeting cards. Unspecific formulations related to new materials, trends, and topicalities were also pointed out. Multipleuse materials, new materials, "from defect to effect", transformation of materials, and application of ecological materials were mentioned. Specific materials and skills, such as painting and alternative methods of painting, glass painting, cosmetology and henna drawings, photography, fishing, etc. were also named.

The fourth category (21\%) represented very unspecific answers that are not related to the content of Home Economics and Technologies. For example, "we learned the basics of everything", "that was my favorite subject", "I learned all feminine skills", "I learned in Lithuania", "it covered all topics", "the fashion trends are changing", "I don't remember", "I don't have an opinion", and "each topic needs more time".

The fifth most popular category was nutriment (18\% of respondents). Most respondents suggested that there should be much more practical training in cooking, that emphasis should be put on healthy diet and lifestyle, on creating menus, and correct preparation of healthful food. Inclusion of hospitality, table manners, and etiquette were also mentioned. Specific topics such as preparation of dairy dishes, various cuisines, cooking of popular and modern meals, preservation, confectionery, herbal teas, and e-substances were marked. Men specifically emphasised the necessity of practical cooking skills.

The sixth most relevant category was household and home economics (11\%). A wish related to agricultural topics such as horticulture and floriculture was specifically expressed. Other topics were related to the planning of budget and resources, upholding and managing of the household, waste sorting and application of household chemicals, inventory of readings, and indoor repair works and furniture repair.

With less proportion (3\% and less), such categories as ethnography, interior design, composition and color teaching, life skills, establishment of a family, and childcare were mentioned. Very little attention was paid to the category of technologies, computers, and equipment. See Figure 6. 


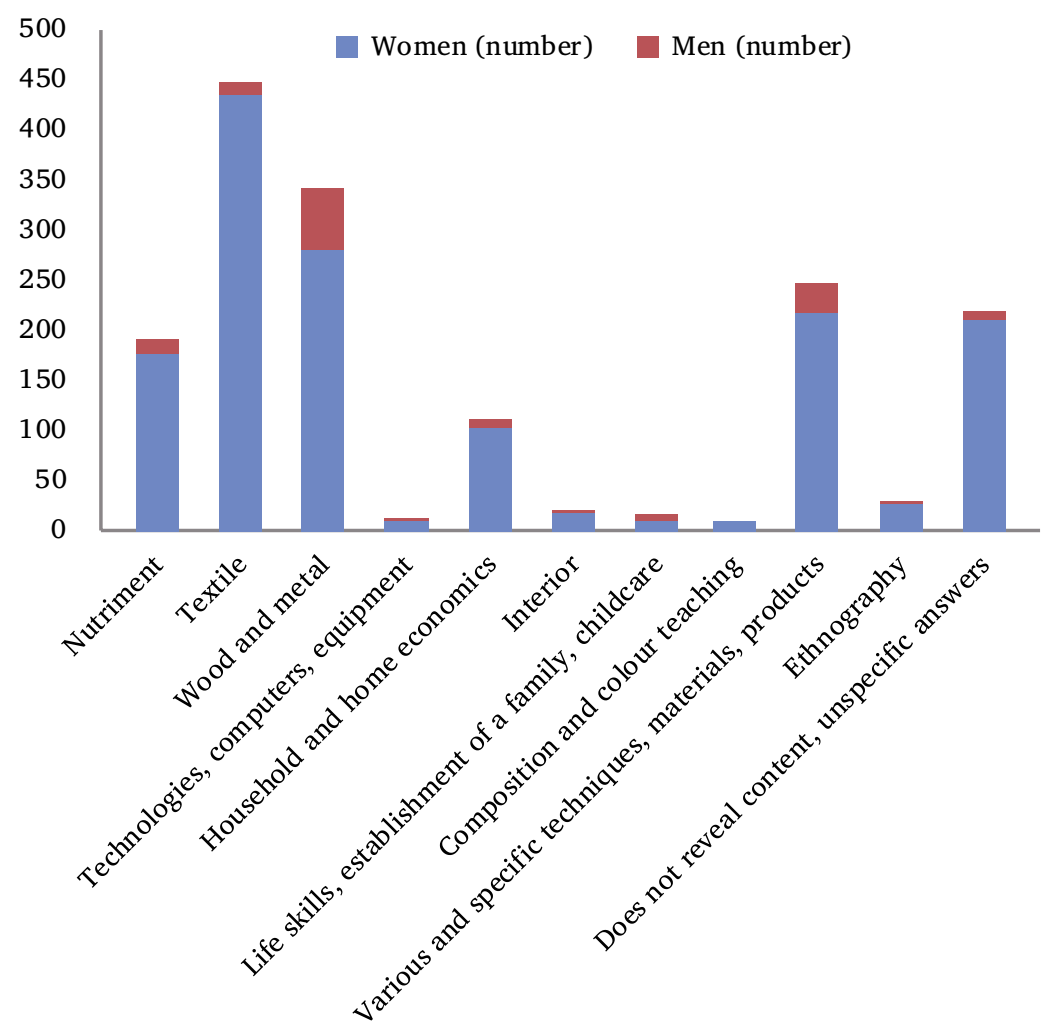

Figure 6. Respondents thoughts about teaching topics that were absent in Home Economics and Technologies and that they would like to learn

Related to the question of what topics should be definitely acquired, the most popular answer was nutritional education, pointed out by 643 respondents (60\% of respondents). As respondents' answers differed in terms of gender, they were further analysed for each gender separately. The largest percentage of women (65\%) indicated nutritional education as a compulsory subject, followed by sewing (35\%), knitting (30\%), crochet (20\%), and clothing (16\%). Attention should be paid to the fact that $12 \%$ of women indicated "all handicraft" as a compulsory subject. Whereas men mostly mentioned woodworking ( $38 \%$ of men), followed by nutritional education (24\%), metalworking (23\%), technical drawing (18\%), and electricity (14\%). See Figure 7.

The respondents' answers related to the question in which directions the subject should be developed did not significantly differ by gender. A strong focus was on content development (17\%). 15\% of respondents wanted more practical tasks, making products that can be utilised in everyday life. $12 \%$ of respondents would not change anything; Home Economics and Technologies 


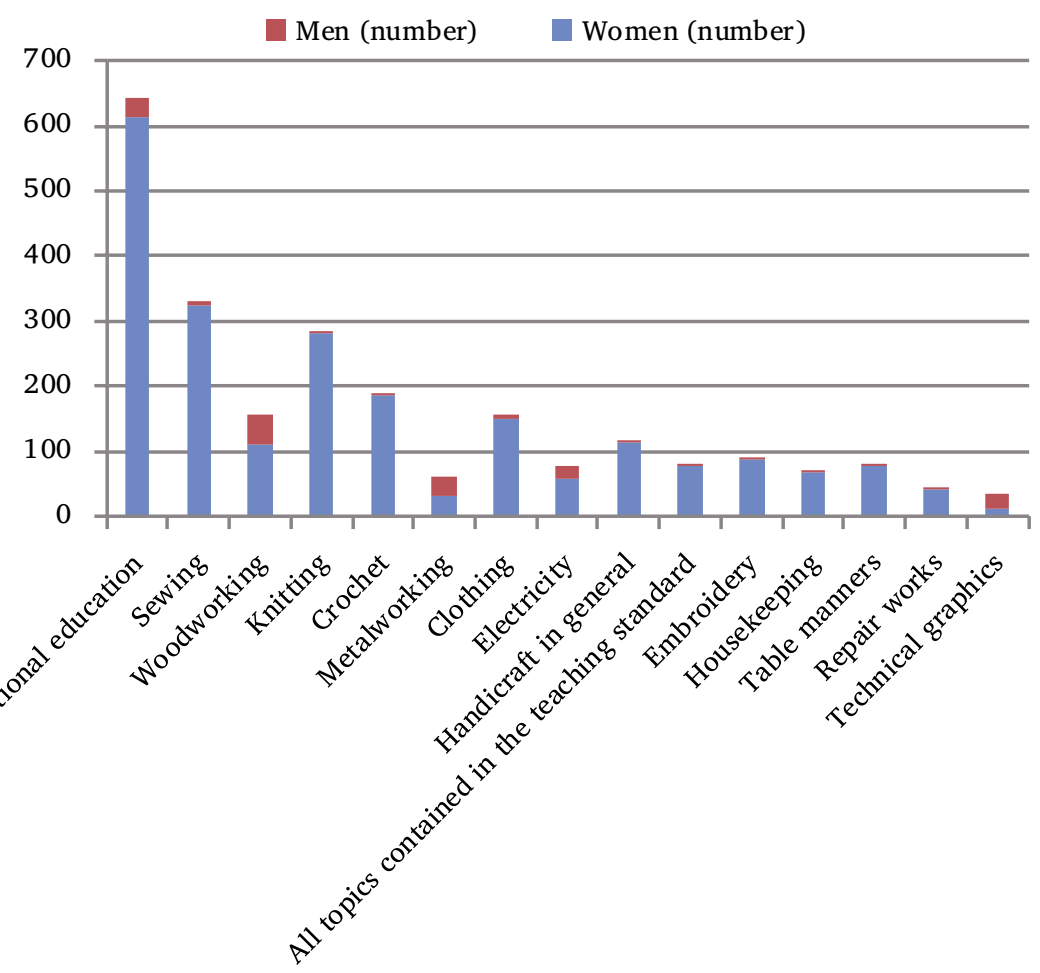

Figure 7. Respondents' views concerning learning topics that should definitely be included in the content of Home Economics and Technologies subject

had been their favorite subject. $12 \%$ of respondents suggested an improved methodology, stimulation of greater interest, use of educational excursions, teamwork, an introduction of a teacher's assistant, and more freedom of choice to pupils. The respondents' answers prove that $9 \%$ of them wanted to bring in more innovation, freedom of choice, creative works, a creative approach, new types of handicraft, opportunity for teachers and pupils to diversify more, diversity, and multilateralism. 9\% of respondents answered that they did not know what they would change as they had no direct link with school, they did not know the current programme, and the situation in each school differs. 7\% of respondents suggested introducing more classes per week as well as introducing it as a compulsory subject also in secondary school, and increasing the number of classes for those who want to get an in-depth learning. $6 \%$ of respondents suggested not breaking the subject by genders, to teach boys some theme elements that are tailored for girls and vice versa, common activities for boys and girls, and classes divided into groups to ensure individual work. $6 \%$ of respondents wanted less volume of work, more work in classes and more adjustment to each pupil 
according to his/her skills. 5\% of respondents suggested improving the material supply base, better-equipped workshops, innovative technologies, and implementation of modern materials. $3 \%$ of respondents suggested reviewing the assessment, putting enrolled/non-enrolled instead of marks, and assessing attitude and work according to accomplishments during the class (see Figure 8). Similar results were obtained from the interviews $(N=14)$ with Latvian students who have been in the student exchange programme in foreign universities. The results shows that the greatest number of suggestions (19 content classifiers from 49) is in the category 'Supplement curriculum'. Students suggest different content aspects for development of the Home Economics and Technologies: introducing other techniques, such as felting and bead crocheting, the use of untraditional and recycled materials, and combining wood, textiles, and metal. Three stress modern elements. The next most-frequently mentioned categories are 'Supplement teaching methods' (10 content classifiers), 'Improve material availability' ( 9 content classifiers) and 'Encourage student self-expression' (5 content classifiers) (Urdziña-Deruma, Šelvaha, 2018).
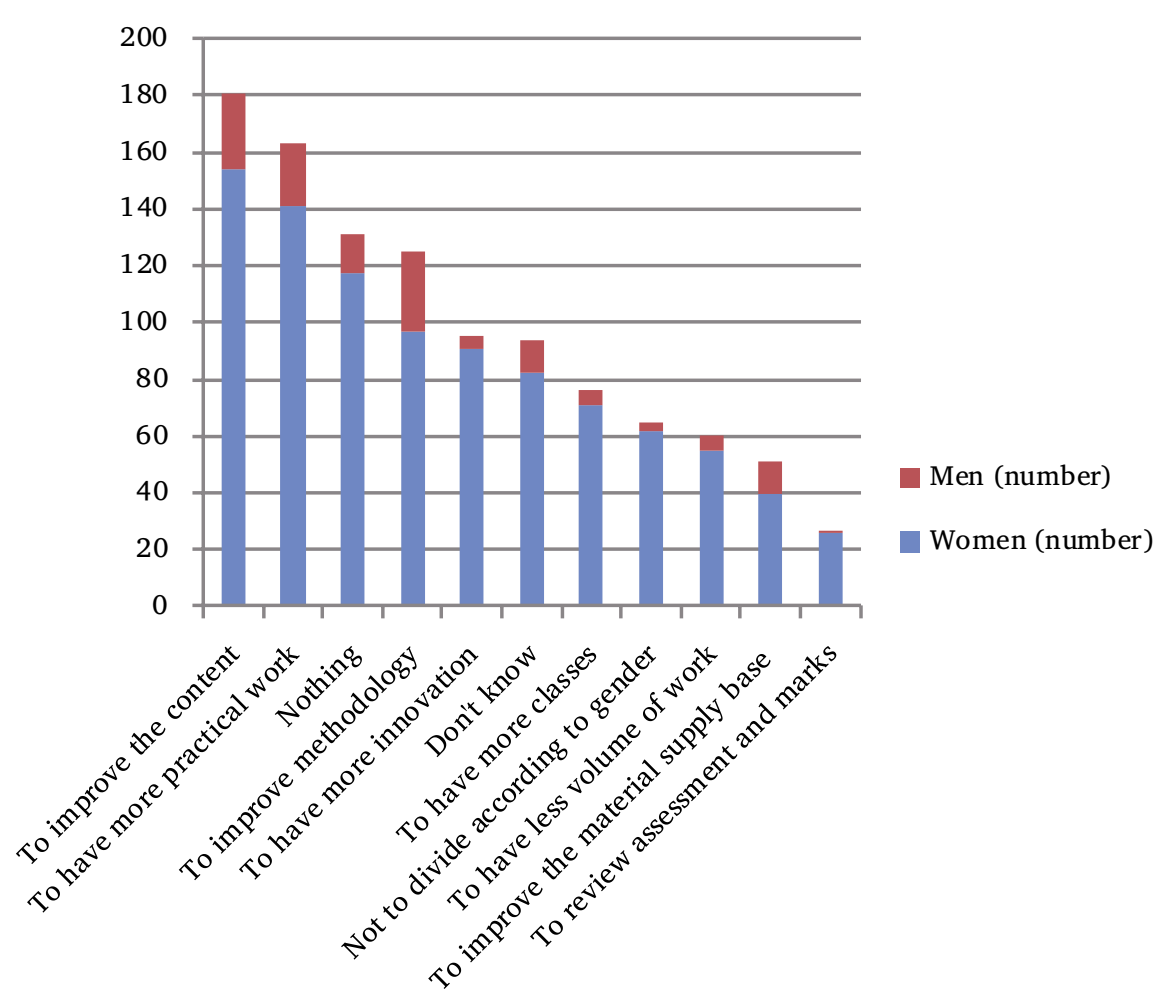

Figure 8. Respondents' views on the development of Home Economics and Technologies subject 
According to the respondents, the most important and essential contribution of Home Economics and Technologies in the education of pupils (339 respondents) was skills and competencies that can be applied in the household. The term "life skills" often appeared in the answers.

As the most important aspect many (242) respondents mentioned specific practical skills in various handicraft techniques, work with different materials, instruments, and creation of various useful products. Many respondents (115) thought that the main aspects were creativity, development of creative thinking, and the ability to express and implement ideas. Almost as many respondents indicated theoretical and practical knowledge as a benefit. Many respondents stressed the importance of handicraft by pointing out that it is important to create things, not just look at them on the Internet. Manual work improves motor coordination. Apart from that, development of fine motor skills in fingers has been mentioned as the main benefit. 55 of respondents thought that the greatest benefit was the gained experience that serves as a foundation for independent living. Many respondents (53) pointed out it is very important that pupils learn to comprehend how things are made and thus evaluate them. In some responses, the ability to work according to a scheme, technical drawing, description, and instructions were mentioned. Development of mind and thinking was named as a benefit. By practical working, the logical and dimensional thinking is
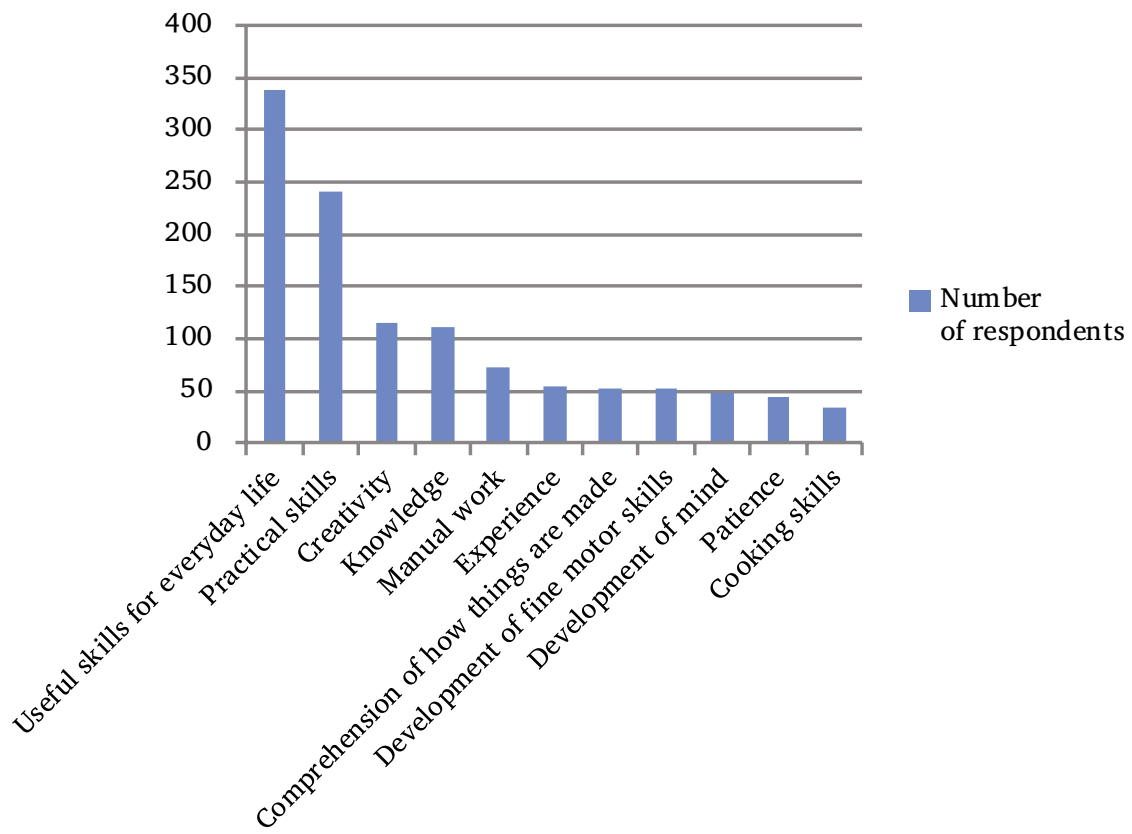

Figure 9. Respondents' views on the main benefits pupils gain by learning the content of the Home Economics and Technologies subject 
trained. Respondents pointed out that the impact of Home Economics and Technologies on the development of positive character traits is very important; it stimulates patience, precision, and accuracy, self-dependence, self-confidence, responsibility, attention, diligence, and sense of taste. Learning cooking skills, including table setting and awareness of nutritional education, was separately pointed out as a special benefit (see Figure 9).

Responses that were mentioned fewer than 30 times were not included in the figure. The mentioned benefits included: deriving insight into various occupations; chance to find one's own hobby; identification of interests and talents; learning of historical heritage and traditions; getting prepared for family life; planning skills (regarding time and resources); and cooperation skills.

\section{Conclusions}

The results of the study show that Latvian society considers the teacher's competence and material supply provision of workshops as the main aspects of ensuring a quality Home Economics and Technologies subject. As for the most substantial contribution in pupils' teaching, respondents see skills that can be applied in the household. It shows that according to the theory about pedagogical models of handicraft education (Pöllänen, 2009) the expectations of Latvian society mostly conforms to the model "Craft as skill and knowledge building". It shows that Latvian society expects to acquire existentially important skills from this subject. A comparatively small portion of respondents emphasised creation of specific products, creation of design objects, and craft as learning of artistic self-expression. There were comparatively few responses indicating the importance of the aesthetical aspect. When responding to the question on what changes respondents would like to see in the subject, the majority of respondents wanted to have more practical work. Respondents had varying views on whether all topics that had traditionally been optional for pupils should be learned by all pupils equally. To a large extent, it relates to the differences appearing in men's and women's responses about the necessary learning topics. A majority of female respondents thought that nutrition should be a compulsory topic (65\%). This was followed by sewing, knitting, crochet, and clothing. A majority of the male respondents indicated woodworking (38\%), followed by nutritional education, metalworking, technical graphics, and electricity. There was a contradiction regarding the fact that learning about traditional cultural heritage was mentioned as a quality criterion by only a few (10) respondents, and as the most substantial benefit by 26 respondents, whereas when talking about topics that should be learned, the acquisition of traditional techniques prevailed. 


\section{References}

Anspaks, J. (2006). Mākslas pedagogíija. 2. daḷa. Metodologija. Teorija. Prakse (Art pedagogic. Part II. Methodology. Theory. Practice). Rìga: RaKa.

Blinkena, A. (Ed.). (2000). Pedagogijjas terminu skaidrojošā vārdnica: aptuveni 1500 terminu latviešu, anglu, vācu un krievu valodā (Explanatory Dictionary of Pedagogical Terms: 1500 terms in Latvian, English, German and Russian). Sast. aut. kol. Valentīnas Skujinnas vadībā. Rīga: Zvaigzne $A B C$.

Borg, K. (2006). What is sloyd? A question of legitimacy and identity. Theme: SloydTradition in transition. Journal of Research in Teacher Education, 2-3, 34-61.

Elorinne, A.-L., Arai, N., \& Autio, M. (2017). Pedagogics in Home Economics meet everyday life: Crossing boundaries and developing insight in Finland and in Japan. In: E. Kimonen, \& R. Nevalainen (Eds.), Reforming Teaching and Teacher Education: Bright Prospects for active Schools (pp. 145-168). Sense Publishers.

Fadels, Č., Bialika, M. \& Trilings, B. (2017). Četru dimensiju izglīïba: Skolēnu panākumiem nepieciešamās kompetences (Four-Dimensional Education: The Competencies Learners Need to Succeeded). Lielvārde: Izglītības uzñēmums "Lielvārds".

Ihatsu, A.-M. (2002). Making sense of contemporary American craft. Publications in education, 73. University of Joensuu.

Izglīî̉a mūsdienu lietpratībai: mācību satura un pieejas apraksts (Education for contemporary competence: description of the content of learning and approach). (2017). Retrieved from https://domaundari.lv/cepure/Macibu\%20satura\%20un\%20pieejas\%20 apraksts.pdf.

Johansson, M. (2006). The work in the classroom for sloyd. Theme: Sloyd-Tradition in Transition. Journal of Research in Teacher Education, 2-3, 152-171.

Kalıke, B., \& Gonzalez Urrea, J. (2016). Dzimumdiferencēta izglītība pedagoơiskajā procesā (Single Gender Education in the Pedagogical Process). Latvijas Universitātes Raksti, 811. sēj. Pedagogija un skolotāju izglitïba (Scientific Papers University of Latvia, Vol. 811. Pedagogy and Teacher Education), 59-66.

Kaukinen, L. (2006). Domains of skills and craft design. In: A.-I. Rauma, S. Pöllänen, \& P. Seitamaa-Hakkarainen (Eds.), Human Perspective of Sustainable Future (pp. 143-151). University of Joensuu.

Kroplijs, A. \& Raščevska, M. (2010). Kvalitativās pētniecibas metodes sociālajās zinātnēs (Qualitative research methods in the Social Sciences). $2^{\text {nd }}$ ed. Rìga: RaKa.

Lind, E. (2013). Possibilities for creative self-actualisation in craft. Differences and similarities in handicraft in the $19^{\text {th }}$ and $21^{\text {st }}$ century in Estonian general education schools. The Changing Face of Music \& Art Education, 5(1), 149-159.

Lutnæs, E. (2013). Regimes of competence in the subject art and crafts. Techne Series A, 20(3), 76-87.

Luutonen, M. Koskennurmi-Sivonen, M., Koski, J. T., Raunio, A.-M., Kirsti SaloMattila, K., Seitamaa-Hakkarainen, P. \& Syrjäläinen, E. (1999). Research at the Section of Craft Science and Textiles Teacher Education at the University of Helsinki. Retrieved from https://rkosken.kapsi.fi/tyorukkanen-en.pdf.

Mājturïba. Pamatizglitibas standarts (Handicraft and Home Economics. Curriculum for elementary education) (1998). Latvijas Republikas Izglītības un zinātnes ministrija Izglìtỉbas satura un eksaminācijas centrs (Ministry of Education of Latvian Republic, Centre for the Content of Education and Examination). Rìga: SIA "Mācību apgāds NT". 
National curriculum for basic schools (2014). Estonia: Riigi Teataja. Passed 06.01.2011. Retrieved from https://www.riigiteataja.ee/en/eli/524092014014/consolide.

Noteikumi par Profesiju klasifikatoru, profesijai atbilstošiem pamatuzdevumiem un kvalifikācijas pamatprasībām (Regulations regarding the classification of occupations, basic tasks and essential qualifications of the profession). (2017). Latvija: Ministru Kabinets. Pienemts 23.05.2017. Retrieved from https://likumi.lv/doc.php?id $=291004$.

Noteikumi par valsts pamatizglitibas standartu, pamatizglitibas mācïbu priekšmetu standartiem un pamatizglitibas programmu paraugiem (Regulations regarding the National elementary education standard, elementary education subject standards and examples of elementary education syllabus) (2014). Latvija: Ministru Kabinets. Retrieved from http://likumi.lv/ doc.php?id $=268342$.

Pöllänen, S. (2009). Contextualising craft: Pedagogical models for craft education. International Journal of Art \& Design Education, 28(3), 249-260. DOI: 10.1111/ j.1476-8070.2009.01619.x.

Root-Bernstein, R. (2015). Arts and crafts as adjuncts to STEM education to foster creativity in gifted and talented students. Asia Pacific Education Review, 16(2), 203-212. Retrieved from https://doi.org/10.1007/s12564-015-9362-0.

Syrjäläinen, E. \& Seitamaa-Hakkarainen, P. (2014). The quality of design in $9^{\text {th }}$ grade pupils' design-and-make assignments in craft education. Design and Technology Education: An International Journal, 19(2), 30-39. Retrieved from http://ojs.lboro.ac.uk/ojs/index. php/DATE/article/view/1931/1972.

Urdziņa-Deruma, M. \& Mīlgrāve, I. (2014). Rokdarbu kā mākslas jomas vēsturiskā attīstība (Historical Devolopment Manual Training as a Branch of Art). Latvijas Universitātes Raksti, 795. sēj., Pedagoğija un skolotāju izglitïba (Scientific Papers University of Latvia, Vol. 811, Pedagogy and Teacher Education), 114.-129. lpp.

Urdziņa-Deruma, M. \& Šelvaha, L. (2018). Crafts and Home Economics studies abroad. Students identified differences and suggestions for teacher education in Latvia. International Journal of Smart Education and Urban Society, 9(4), 77-89.

Urdziņa-Deruma, M. (2001). Tekstils kā mākslas izglītības sastāvdalı topošo mājturïbas skolotāju studijās augstskolā (Textile as a Part of Art Education in the Studies of Future Teacher's of Handicraft and Home Economics in Higher Education Institution). Doctoral dissertation. Retrieved from https://dspace.lu.lv/dspace/handle/7/546.

Žukovs, L. (1987). Darbmācības satura attīstības tendences Latvijas vispārizglītojošajās skolās (Tendencies of developing Manual training content in LSSR general schools). In: Mācību un audzināšanas satura attīstības galvenās tendences Latvijas PSR vispārizglītojošajā skolā (Tendencies of developing of the content of learning in LSSR general schools) (pp. 72-89). Rīga: LPSR IM. 